This article was downloaded by: [Canadian Research Knowledge Network]

On: 27 April 2011

Access details: Access Details: [subscription number 932223628]

Publisher Routledge

Informa Ltd Registered in England and Wales Registered Number: 1072954 Registered office: Mortimer House, 3741 Mortimer Street, London W1T 3JH, UK

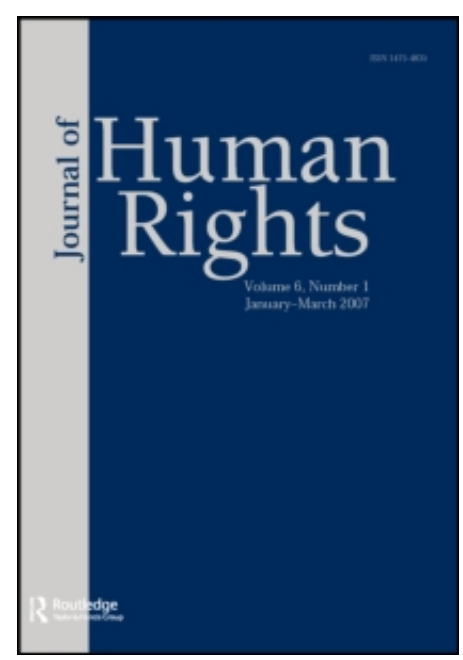

\title{
Journal of Human Rights
}

Publication details, including instructions for authors and subscription information:

http://www.informaworld.com/smpp/title content=t713431618

\section{The State of "Sorry": Official Apologies and their Absence}

Alice MacLachlan ${ }^{\mathrm{a}}$

${ }^{\text {a }}$ York University, York, UK

Online publication date: 19 August 2010

To cite this Article MacLachlan, Alice(2010) 'The State of "Sorry": Official Apologies and their Absence', Journal of Human Rights, 9: 3, $373-385$

To link to this Article: DOI: $10.1080 / 14754835.2010 .502085$

URL: http://dx.doi.org/10.1080/14754835.2010.502085

\section{PLEASE SCROLL DOWN FOR ARTICLE}

\footnotetext{
Full terms and conditions of use: http://www.informaworld.com/terms-and-conditions-of-access.pdf

This article may be used for research, teaching and private study purposes. Any substantial or systematic reproduction, re-distribution, re-selling, loan or sub-licensing, systematic supply or distribution in any form to anyone is expressly forbidden.

The publisher does not give any warranty express or implied or make any representation that the contents will be complete or accurate or up to date. The accuracy of any instructions, formulae and drug doses should be independently verified with primary sources. The publisher shall not be liable for any loss, actions, claims, proceedings, demand or costs or damages whatsoever or howsoever caused arising directly or indirectly in connection with or arising out of the use of this material.
} 


\title{
Review Essay
}

\section{The State of "Sorry": Official Apologies and their Absence}

\author{
ALICE MACLACHLAN
}

The Age of Apology: Facing Up to the Past by Mark Gibney, Rhoda E. Howard-Hassman, Jean-Marc Coicaud, and Niklaus Steiner, Editors. Philadelphia: University of Pennsylvania Press, 2008. 344 pp. $\$ 26.50$, paperback.

The Politics of Official Apologies by Melissa Nobles. New York: Cambridge University Press, 2008. 214 pp. $\$ 24.99$, paperback.

Resentment's Virtue: Jean Améry and the Refusal to Forgive by Thomas Brudholm. Philadelphia: Temple University Press, 2008. 256 pp. \$24.95, paperback.

The late twentieth and early twenty-first centuries have been called the age of apology by a number of academics and political figures. Exact numbers vary, but even at a conservative estimate, there have been over 50 official apologies offered by heads of state, government representatives, as well as the leaders of churches, corporations, and other nongovernmental organizations in the last several decades. ${ }^{1}$ And the list of actual apologies is of course much shorter than the list of individuals and groups who have demanded apology during the same period, but whose demands have thus far been denied or ignored: infamous examples of non-apologies include the Turkish government's refusal to apologize for the Armenian genocide of 1915, and the American government's refusal to apologize for slavery. ${ }^{2}$ Apologies and their absence have emerged and remained in focus within broader efforts to respond morally and politically to historical injustices, postcolonial legacies, and authoritarian rule, as well as the atrocities of genocide, crimes against humanity, and the violence of civil and ethnic conflict.

Despite this phenomenon, the academic literature on apologies has only just begun to catch up to the literature on various other aspects of repair following serious wrong: forgiveness, reconciliation, amnesty, and pardons. Prior to 2008, there were only a handful of book-length treatments, most notably by sociologist Nicolas Tavuchis (1991) and psychologist Aaron Lazare (2004). Philosopher and legal scholar Nick Smith was able to open his 2008 monograph, I Was Wrong: The Meaning of Apologies, with the bold, if entirely plausible, claim that his was the only philosophical monograph dedicated solely to the topic of apologies since Maimonides' Hilchot Teshuvah, circa 1170. Moreover, the interdisciplinary volume The Age of Apology (Gibney et al. 2008) discussed in this essay is, to my knowledge, the first of its kind. 
The dearth of books on apologies is particularly striking if we consider that only the apology, from among the concepts listed above, makes its primary demand of the perpetrator and not the victim of wrongdoing. The call for an official apology, and thus for a change in the authoritative historical record, can be read as an important continuation of the policy of "speaking truth to power," originating in Quaker communities and taken up by the human rights and civil rights activists in the twentieth century. At the same time, many observers are cynical of the new politics of apology, dismissing it as cheap, "gestural politics" awash in self-interest and crocodile tears, which enable governments and leaders to defuse angry minority groups without committing any actual resources to the problems of injustice and exclusion (Cunningham 2004).

Neither the optimism nor the cynicism surrounding apologies appear entirely misplaced: In one recent example, the Australian government officially apologized to Australian Aboriginal peoples for a history of government policies that included the forcible removal of "half-caste" Aboriginal children from their families, for the purposes of saving and "whitening" them. This was a hard-won victory for Aboriginal peoples and their allies, as the previous Liberal government, led by Prime Minister John Howard, had refused to endorse what Howard called a "black armband view of history" for almost a decade, even in the face of widespread public support for an official apology and grassroots movements like national "Sorry Day" and the signing of "Sorry" books. Yet, while Labour Prime Minister Kevin Rudd acknowledged in his speech the "the indignity, the degradation, and the humiliation these laws embodied" and the "families and communities whose lives were ripped apart by the actions of successive governments under successive parliaments," there was no compensation package for victims and their families attached to the much-publicized apology (Rudd 2008). What commitments the apology did make toward improving the material conditions of life for Australia's Aboriginal peoples were left vague and ultimately fell short of those recommendations made by the Bringing Them Home report, which had initiated the drive for apology ten years earlier. ${ }^{3}$

How then can theorists and observers best make sense of the sudden proliferation of apologies on the political stage? Given the solemn weight of history apologies seem to carry, and the passion with which victimized groups demand them, subjecting apologies to critical analysis can feel inappropriate, even blasphemous. At the same time, there remains significant confusion over what, exactly a particular apology is meant to achieve or offer, and by what standards we ought to evaluate it. Given the kinds of serious and longstanding wrongs for which state actors and public figures are called upon to apologize, what-if anything - could possibly qualify as a good or satisfying apology? What is it exactly that a public apology is meant to do or accomplish? Apologies-as well as the needs, rights, attitudes, and responses of victims that lead to demands for apologies-require contextualization and thematization. This task is taken up, in various ways, by the three books discussed in this essay.

The essays collected in The Age of Apology explore the emerging practice of public apologies by primarily Western nations from a variety of disciplinary perspectives. The aim of the collection, its editors explain, is not only to account for the rapid proliferation of public apologies over the last 20 years but to situate the rise of the public apology thematically: connecting it to postcolonial relationships between former colonizers and the colonized, to the rise of social movements like the civil rights movement, and indigenous people's demands for sovereignty, and to difficult questions of collective and intergenerational responsibility for past wrongs.

The Age of Apology consists of 20 individual essays, divided into five sections. The first section addresses the meaning of apologies from the perspective of contemporary legal, 
political, and ethical theory, with some cross-cultural comparison. The remaining sections present, collectively, a typology of public apologies: They cover, in turn, "internal" state apologies - that is, government apologies to minority groups in their own population, international apologies between states, and apologies by nonstate actors (papal apologies and corporate apologies). The final two essays address "the war on terror" as an apparent exception to all categories; a decision that itself is suggestive of the limits to any such typology. ${ }^{4}$ The cases chosen to illustrate these different types of public apology range geographically and historically: from the Treaty of Waitangi settlement process between New Zealand's government and the indigenous Maori people, to the German minister for economic cooperation and development's apology for atrocities committed in the former German South-West Africa (Namibia), to "quasi-apologies" by the Canadian government, and a perceived lack of apology by Japan to its South Asian neighbors, most notably China and Korea, for atrocities committed during the Second World War.

Because of its interdisciplinary and its collective nature, The Age of Apology can usefully be seen as a representative example of the present state of academic literature on apology. Several features are worth noting-first and foremost, the wide view taken of what constitutes a public apology. Contributors to the volume consider apologies by corporations, church leaders, and the media, as well as those by heads of state or governments. This inclusive approach is exemplary of the literature as a whole, which has developed increasingly complex and inclusive criteria for mapping apologies. ${ }^{5}$ Theorists are no longer satisfied to mark off apologies as collective or interpersonal but focus also on the kind of authority the apologizer is taken to have (whether representative, ceremonial, corporate, or celebrity), on the nature and the historical location of the wrong (discrete or ongoing; in the recent or distant past) and on the identity of the individual or group demanding an apology in the first place (whether primary victims, their political representatives, or indeed their descendents). The authority, the content, and the addressee of a given apology are understood to be crucial in locating both its meaning and its purpose; as these elements vary, so does the import of the apology.

Equally exemplary of the broader literature is the lack of consensus over what actually constitutes an apology, official or otherwise. Commentators disagree over the extent to which apologies are "mere" speech and should be assessed as such or, rather, if a genuine apology includes other meaningful actions (for example, reparation or compensation). Theorists of apology have tended to understand them in terms of speech-act theory, drawing on the work of British philosopher J. L. Austin (1975) and concluding that they "can only be done with words and, by corollary, if [they] are not done in the words, [they] have not been done" (Bavelas 2004: 1). But it is not clear that apologies are always done in words, or at least, not the same words each time; this is particularly true in the public realm, where "apologies can be communicated in a wide range of ways, through verbal statements issued publicly, joint declarations, legislative resolutions, documents and reports, legal judgments, pardon ceremonies, apology rituals, days of observance, reconciliation walks, monuments and memorials, even names bestowed on the landscape" (Weyeneth 2001: 20). Furthermore, the notion of speech act does not yet convey the extent to which apologies may be ritualistic and ceremonial. Sanderijn Cels argues that we should focus less on apologies as speech and more on apologies as performances, drawing on the resources of dramaturgical theory to interpret their ceremonial significance. ${ }^{6}$ Nick Smith also includes performance among the elements of what he calls a "categorical apology": the regulative ideal guiding our various practices of apologizing — both in public and in private, individually and collectively (Smith 2008: 74). 
The difficulty of categorizing apologies as speech emerges at various points in the volume. While most contributors rely on standard speech-act definitions of apology, some challenge it; and one of the editors, Mark Gibney, has argued in previous works for two nonvocal performative elements, "publicity" and "ceremony," as crucial criteria for an authentic public apology (Gibney and Rockstrom 2001). Furthermore, the tendentious relationship between speech and action arises in Carlos Parodi's piece on "State Apologies Under U.S. Hegemony." Parodi considers how US political influence in Latin America has complicated local efforts to come to terms with past human rights violations. It would be too easy, he notes, to assume that Latin American truth commissions are mere tools of US power and interests in the region, but he concludes that until the United States is included in these processes as a responsible actor, apparently benevolent gestures such as President Clinton's 1999 apology for American support of repressive military forces in Guatemala will have little lasting effect on the region. Apologies do not count as such without the support of transformative actions.

Similarly, Rhoda Howard-Hassmann and Anthony Lombardo's empirical research on the reception of Western apologies by educated Africans ("Words Require Action: Africa Elite Opinion About Apologies from the "West") notes a remarkable level of consensus among those they interviewed: "without actions, they believed, words are meaningless" (Gibney et al. 2008: 218). Since apologies are at least partly normative-that is, part of what makes something an apology is the author's intention to accomplish something of moral value - the line between whether action is required for something to be a good apology or for something to even be an apology tends to blur. Meaningless, empty, or failed apologies may not merely be bad apologies, they may fail to be apologies at all.

There is also significant dispute over the extent to which tone and sincerity should affect our evaluation of a political apology. The wrong tone or obvious insincerity can undermine the import of an apology but can the right tone guarantee it? J. L. Austin assigned apologies to the class of behabitives; statements or utterances that are concerned with attitudes and feelings (Austin 1975: 83). But feelings and attitudes are clearly not the only things with which apologies concern themselves. In fact, most apologies perform multiple functions. First, they have a narrative function: Apologies identify the wrongdoing as such, the apologizer as responsible for it, and the victim or addressee as wrongfully harmed by it. Second, apologies communicate disavowal; in apologizing, the wrongdoer distances oneself from her acts even as she takes responsibility for them, repudiating the attitudes, motivations, and circumstances that led her to perform them. Finally, apologies represent a form of commitment, both to the apologizer's ongoing disavowal and her good-faith efforts to repair the wrongs as she is able and as is appropriate. Feelings and attitudes only appear as the vehicles for these primary functions. At least in our interpersonal relationships to others, we achieve disavowal and distance from past actions through our attitudes towards them. These attitudes are what motivate our commitment to be different or better.

Difficulties thus arise in the public, political realm, where personal feelings and attitudes do not (and perhaps should not) play the same motivational role. Theorists of political apology have struggled to provide appropriate motivational measures that might form the basis for evaluating "good" and "bad" public apologies, but they disagree over whether this is to be found in attached material compensation, changes to the historical record, the affective responses of addressees and witnesses, or in terms of a renegotiated political relationship between apologizer and addressee (or indeed, in all of the above). To treat the first, material compensation, as a standard seems to render the apology itself almost irrelevant, and the second, historical record, does not seem to depend on tone or mood but could also, presumably, be accomplished by acts other than an apology. Yet the third is 
hard to quantify, or even comprehend. The debate remains at an impasse, and the editors of this collection remark - and rightly so - that, for the present, political apologies must be viewed with a mixture of hope and unease (Gibney et al. 2008: 8).

Several contributors to The Age of Apology correctly emphasize that academic analysis of public apologies has not yet matured; that is, there is little consensus—or, as of yet, even structured debate - over the meanings, features, or desiderata of public apologies. This can leave the observer with the vague sense that theorists of public apologies are talking past one another. If this volume has one serious shortcoming, it is that it does little to correct this impression. So, for example, Renteln's cross-cultural analysis of apologies notes that the idea of apologies as necessarily "sincere, heartfelt or voluntary" may be more localized than many have recognized, and that apologies may serve different purposes in societies with norms organized around shame as opposed to guilt (Gibney et al. 2008: 68-69). Yet, in the very next essay (Jean-Marc Coicaud and Jibecke Jönsson, "Elements of a Road Map for a Politics of Apology") the authors start from the-presumed universal-premise that "for the offering of apology to have a real value, it is essential that the remorse conveyed is genuine" (78). Further conversation among contributors might also have served to connect the theoretical discussions of apologies in Part I to the cases and examples illustrated in subsequent chapters. Instead, it seemed as if each contributor was required to offer his or her own introductory framework. Indeed, this was not always a bad thing, as some later discussions of the political and legal theory of apologies were more insightful than the opening chapters. But the overall impression was one of inconsistency and sometimes incommensurability, rather than dialogue and engagement. ${ }^{7}$

The complexity described in the pages of The Age of Apology (and toward which I have tried to gesture, above) demonstrates that there is not yet a conclusive method for understanding all instances of public apologies. Perhaps we do better, then, when we refrain from asking, "What is the meaning of the public apology?" where the question is taken to be general, applying to all contexts and instances. Instead we might ask, "What is the meaning of this particular apology, or these apologies, in this context and in these circumstances?" Melissa Nobles takes up the second, more focused task in her book titled The Politics of Official Apologies.

The Politics of Official Apologies offers a "membership theory of official apologies," based on an analysis of five specific contexts in which the demand for apology has been made: the plight of indigenous peoples in Australia, Canada, New Zealand and the United States, as well as that of African Americans. The membership theory of apologies that Nobles advocates is based on the following claim. While individual political actors may have various individual reasons and motivations for pursuing a course of official apology, ultimately, such apologies function as part of ongoing efforts to reshape the terms of membership in a national political community, where membership is taken to have legal, political, and affective dimensions. We can assess the merits and the success of particular apologies, she argues, based on their responsiveness to and their effects on these three dimensions of the relationship between the minority in question and the larger political community (Nobles 2008: 36-37). Study of the five cases in question reveals how official apologies have, on occasion, been able to play this political role.

Apologies are capable of performing the moral and political task of renegotiating membership, Nobles claims, because they officially acknowledge historic injustices and thus create grounds for rectification, the reshaping of political arrangements, and other policy changes. The effects of apologies on the affective dimensions of membership, she notes, are far less predictable: Public reaction to even the mention of apology can (and does) vary widely from country to country, with a majority of Canadians tending to support 
government apologies, for example, while in the United States, the suggestion can raise substantial backlash and anger (Nobles 2008: 138). Apologies differ from other responses to wrongdoing, such as reparations, in that they are symbolic and do not offer financial or material relief, but Nobles is right to point out that they ought to be evaluated on their own terms and not dismissed as materially useless (143-144). The difficulty, as noted above, is determining what exactly those terms are: Nobles' strategy is to show the concrete effects of at least some apologies to draw out some more general aspects of their significance and function.

The comparative examples Nobles employs are well chosen for their similarities; because all four countries are settler societies and former British colonies, the dominant (though not homogeneous) Anglo-European culture in all four ensures some degree of cultural convergence regarding the nature, meaning, and propriety of apologies. ${ }^{8}$ Furthermore, in all cases the demand for apology arises on behalf of a small minority of the population and is rooted in grave historical injustices - the seizure of land, cultural colonialism and appropriation, illegitimate subjection to the state, violent and forcible removal, and slavery-as well as an ongoing history of formal and material inequality. Yet the differences between these cases are also telling: The demands of indigenous peoples tend to focus on three aspects: land claims, self-government, and cultural preservation. The demands of African Americans are somewhat different and-as Nobles notes-are concerned less "with the goals of formal equality than with their nonachievement and limits" (2008: 19).

Furthermore, there are significant disanalogies between the history of indigenous peoples in settler societies and that of African Americans. Nobles is careful to acknowledge these disanalogies explicitly and their consequences for her analysis (African Americans get short shrift in the book's middle chapters) noting that "African American-related apologies (and nonapologies) are not among the book's main cases" (2008: 39), but the result is that the intended scope of her analysis is unclear: That is, whether the membership apology is meant to apply to all cases of government apologies to oppressed internal minorities or only to indigenous peoples as a special case. The membership theory of apologies-with its focus on the legal and political dimensions of membership as well as affective, subjective relationships_-seems particularly compelling in the case of indigenous peoples, whose legal and political status has been especially complex, ranging historically from state "wards" to asymmetrical notions of "registered Indian" or "citizens plus" (Nobles 2008: 44-46) and which is still in debate today. ${ }^{9}$ I am not sure it would apply as cleanly to all cases of historical injustice, especially when the demand is for recognition and acknowledgment of a discrete past wrong, made by citizens whose current legal and political status is relatively unproblematic, such as Ukrainian Canadians seeking apology for internment during World War I, or Japanese Canadians and Americans seeking apology for internment during World War II.

The middle chapters of The Politics of Official Apologies provide detailed, nuanced yet accessible histories of the indigenous peoples of all four countries. Nobles outlines the many individual factors, players, circumstances, and events that resulted in demands for apology in some cases and not others, and that led to offers of apology in some cases and not others. Her book is a valuable resource for anyone looking to know the details of these political histories. The historical specificity of Nobles' account renders it vulnerable as well as impressive, however, and, in particular, her analysis suffers from some rather unlucky timing. In 2008, the year of her book's publication, our understanding of at least two of the central cases she presents changed dramatically. As I mentioned above, on February 13 of that year, newly elected Australian PM Kevin Rudd offered the apology to Australia's indigenous peoples that his predecessor, John Howard, had so strongly resisted (and whose 
resistance is the focus of much of Nobles' analysis of the Australian case, rendering many of her conclusions about potential Australian reception to such an apology premature).

The second case is perhaps of greater concern. On June 8, 2008, Canadian Prime Minister Stephen Harper also offered an apology to Canada's indigenous peoples for the government's complicity in the Indian Residential Schools, following years of campaigning and lobbying by indigenous activists, international pressure, and — ultimately—a successful lawsuit (Indian Residential Schools Settlement Agreement 2006). Once again, it is simply unfortunate that Nobles' book publication preceded such a relevant event and thus she could not subject it to her analysis. In this case, however, the misfortune is compounded by Nobles' claim that the Canadian government had already uttered an official apology to its indigenous peoples for these government policies. At various points, Nobles takes the "Statement of Reconciliation" issued in 1998 by Jane Stewart, then (Liberal) Minister for Indian and Northern Affairs, to be an official government apology (2008: 116).

Whether or not Nobles is right to treat Stewart's Statement of Reconciliation as an official act of apology is a difficult question, and one that gets at the heart of the confusion surrounding the nature and purpose of political apologies. That is, it raises the issue of standards by which an event even counts as an apology-let alone a good or successful one. A closer look at the text of the statement is instructive in this matter. Nowhere in Stewart's statement, for example, does she use the word "apology" or "apologize." She indicates that Canada must "recognize" and "acknowledge" the effects of its history on its indigenous peoples, and she formally expresses "regret" at the actions of past governments, but that regret is never transformed into the admittedly stronger terms of "responsibility," "remorse," or even "guilt." The statement executes a graceful dance of equivocation, telling the survivors of residential schools that "we wish to emphasize that what you experienced was not your fault and should never have happened"; a remark that—in this context—is almost patronizing and does not go on to locate fault elsewhere. While the statement does go on to say "to those of you who suffered this tragedy at residential schools, we are deeply sorry," but "sorry" in this context is highly ambivalent (and, it appears, intentionally so); it could express remorse, but, equally, it could be merely sympathetic. ${ }^{10}$ Most alarming, perhaps, is the line that introduces the issue: "Sadly, our history with respect to the treatment of Aboriginal people is not something in which we can take pride." The emphasis is selfdirected, albeit critical; it does not reach out to the purported addressee. ${ }^{11}$

Also significant is the broader context of the 1998 statement: It was not uttered by Prime Minister Jean Chretien, then the leader of the Canadian government. Indeed, he did not attend the ceremony, though he was in Ottawa at the time. This contrasts starkly with the 2008 apology, uttered by the Canadian Prime Minister in the Canadian parliament, followed by statements from leaders of all political parties and-most importantly-by a response from Chief Phil Fontaine of the Assembly of First Nations (the political body representing over 50 native tribes) in full ceremonial headdress, alongside leaders from Canada's Métis and Inuit populations. This was the first time indigenous leaders had been invited onto the floor of the house in their capacity as representatives of nations and had been granted permission to speak in that capacity. ${ }^{12}$ The evidence that this was an act of apology, and-moreover-an official one, is overwhelming.

Nobles never comments on the ambiguous title of Stewart's statement, or the absence of words and phrases we typically take to signal the functions of apology. Relying primarily on media accounts from that time, which noted broad public acceptance that the government had indeed "apologized," she treats it as a surprisingly unproblematic example and subjects the statement to less scrutiny than is warranted. Here Nobles might fruitfully enter into conversation with Matt James, one contributor to The Age of Apology ("Wrestling with 
the Past: Apologies, Quasi-Apologies, and Non-Apologies in Canada"). James argues that the novelty and ambiguity surrounding the so-called "politics of apology" —and the lack of a properly political set of criteria for evaluating them-have allowed various levels of Canadian government to represent themselves as more apologetic than is warranted. He differentiates apparent cases into apologies, quasi-apologies, and non-apologies, noting how a preponderance of the latter two has led Canadian observers to overestimate their nation's commitment to redressing the past. What emerges is the sense that determining the nature of a "true" or "genuine" apology is not merely speculative conceptual analysis but may have concrete implications for the politics of apology on the ground.

Nobles is not necessarily wrong in her appraisal and James right in his: There are grounds for arguing that insofar as those involved take a statement to be an apology, it can reasonably be read as such. There is some evidence that the Canadian government intended the statement to be apologetic, or at least sufficiently apologetic, and-as Nobles cites-mainstream media sources were quick to name it so. But on the other hand, response by indigenous leaders and activists was mixed, as was the historical record over time. It is hardly coincidental that in the text of his official response to the 2008 government apology, Chief Phil Fontaine leaves one, rather emphatic, phrase to stand alone, without qualifier: "Finally, we have heard Canada say it is sorry" (2008).

The case of the 1998 Canadian Statement would have been an excellent opportunity for a discussion of apology criteria: Are these internal to the text or to the performance? Should they be determined situationally or more broadly? To what extent are they descriptive, or do they include normative aspects (the extent to which the apparent apology is able to achieve its moral and political function, for example)? As noted by Weyeneth (2001) above, apologies have taken any number of forms. Moreover, there are reasons to avoid highly determinate, strict criteria, insofar as these might fail to represent actual practices and instances of apologizing, but Nobles does not invoke these. ${ }^{13}$

Of course, the apologetic or non-apologetic nature of Stewart's statement might well have remained a matter of interpretive speculation, had the Canadian government not offered an unambiguous apology covering much of the same history, several months after the release of Nobles' book. Furthermore, in offering a "theory" of apologies, Nobles is not engaging in conceptual analysis but political explanation: why people seek them, the conditions under which governments offer them, and what they provide to the broader political venture of responding to past injustice. Indeed, her account as a whole focuses more on analyzing the concept of political membership - that is, its meaning, dimensions and expression as revealed in the histories of four former British colonies - than she does on the concept of apology, or, for that matter, the qualifier "official." As a result, these concepts remain undertheorized, at times to the detriment of her book's main claims. But this lack of analysis does not undermine what I take to be a unique strength of the book: that is, the clear, detailed, and consistently engaging comparative histories of the indigenous peoples of four countries, and the careful detailing of the complex variables involved in their ongoing struggles for recognition and political change, as these make up the bulk of the middle chapters. This book is perhaps most useful to scholars of indigenous rights and indigenous histories, and not to scholars of apologies, but that is no insignificant achievement.

The interpretive difficulties faced by Nobles and others in determining just when an apology has taken place raise interesting questions about the relevance of non-apologies in assessing the politics of apology. As the case with the 1998 Canadian Statement of Reconciliation, we can learn a great deal about what a well-timed apology might have meant or accomplished, by studying those instances in which one was not offered, or in 
which what has been offered should not qualify as an apology proper. Non-apologies or quasi-apologies teach us about the potential moral and political work of apologies, by showing us-sometimes viscerally_-where and how they are unsatisfying. Nobles herself notes that the long list of apologies offered or demanded is dwarfed next to the almost "incalculable" number of instances in which apologies could be appropriately offered but are either refused or not demanded (5). What is left for the victims of wrongdoing, when no satisfying apology is made—or indeed, when no satisfying or sufficient apology could ever be made?

One way to read Thomas Brudholm's text, Resentment's Virtue: Jean Améry and the Refusal to Forgive, is as an extended meditation on the dangers of moving too quickly from the questions of apology, responsibility, and acknowledgment of wrongdoing, to issues of forgiveness, resolution, and reconciliation—or even, of assuming too quickly that the move must be made. Brudholm's purpose, he writes, is to "provid[e] a constructive complement to writings that dismiss various kinds of resentment and refusals to forgive only as the negative to be overcome" (Brudholm 2008: 171). He aims both to rehabilitate resentment as a potentially moral response to serious wrongdoing, and to caution against what he takes to be the overenthusiastic, and at times careless, promotion of forgiveness in recent writings on transitional justice. Of course these two aims are not unconnected; Brudholm sees the current promotion forgiveness as a catch all for responding to moral and political wrongdoing taking place at the expense of legitimate expressions of anger, resentment, and other morally laden reactive attitudes. Insofar as forgiveness is glorified, anger is necessarily condemned. This zero-sum game approach is, for Brudholm, exemplified in the workings - and in subsequent analyses — of the South African Truth and Reconciliation Commission (TRC).

Brudholm's approach to his topic is somewhat unconventional. The book divides in two parts, which are divided in their focus, their content, and their historical era. The first half of Resentment's Virtue is a sustained critique of the TRC and, in particular, the subtle and less subtle ways in which Archbishop Desmond Tutu praised, promoted and encouraged victims who forgave, at times to the point of emotional manipulation. Resentful victims were not actually coerced into forgiveness, of course, and forgiveness was not part of the official mandate of the TRC. All the same, Brudholm demonstrates, resistance to forgiveness was interpreted as temporary, unfortunate (both for them and for society), or even pathologized as a burden they must eventually remove. What emerged was a normative "discourse of reconciliation" (Verdoolaege 2006).

Yet however miraculous the push for harmony and reconciliation at all costs might have been at minimizing the violence and instability in the South African transition from apartheid, it sits in tension with the recognition that transition from evil is not resolvable without "moral remainder," in the words of Claudia Card; that is, that "imbalances, debts, or unexpiated wrongs ... remain even after we have done what can be done to put things right" (Card 2002: 169). Drawing on transcripts, media reports, narratives by victims, and Tutu's own autobiographical account of the TRC, Brudholm gives a compelling and convincing critique of what he himself acknowledges was nevertheless a powerful phenomenon. He concludes at the end of Part I that an excessive focus on forgiveness actually shuts down our ability to acknowledge and respond appropriately to the moral remainders of evil, violence, and serious wrongdoing. It also does significant, perhaps irreparable, damage to victims engaging morally — and viscerally — with the same. Someone wishing to quibble with Brudholm's assessment of forgiveness as a moral concept might note that Tutu's understanding is not universal, or even dominant, in philosophical and psychological discussions of the topic. There are other approaches to forgiveness that lessen its silencing or coercive effects 
on resentful victims. ${ }^{14}$ But his critique of the TRC - and his wider point about promoting forgiveness in political contexts-is extremely well taken.

In Part II, Brudholm shifts from the operations of the South African TRC of the 1990s, to the writings of Jean Améry, a Jewish Holocaust survivor in postwar Germany. It is here that he hopes to reveal the virtue of resentment, or ressentiment, as expressed in Améry's essays. Brudholm intends the sudden shift in history, geography, and focus to be jarring, as is the move from public transcripts to personal essays, and the supposedly "backwards" shift from forgiveness to resentment-in this, he is successful.

$\mathrm{He}$ is less successful, perhaps, in connecting his discussion of Améry to the wider project of the book. It is not clear what relationship Brudholm sees between the functioning of the TRC and the experiences of Améry; one is a public discourse and the other a set of private reflections. Is the latter a straightforward [if anachronistic] rebuke to the former, or does it hint at some constructive alternative? How might the insights of Améry be applied to the mechanisms of transitional justice, beyond the vague caution that the responses and experiences of victims must be attended to? He cites Améry as stressing that "the book is not a documentary work, but rather an examination or a phenomenological description of the existence of the victim" (Brudholm 2008: 69). The reader is left to convert phenomenological description into the "virtue" promised in the title. What emerges is some sense that resentment can play a central role in an ongoing effort to manage and understand the past, to resist the message and values of wrongdoing, and to find morally appropriate ways to relate to others (both perpetrators, bystanders, and other victims). It's not clear that this demonstrates a virtue of resentment, but it certainly demonstrates its potential value, and Brudholm is right that this insight is missing from the pages of Tutu's reflections on the TRC. But, as Brudholm himself acknowledges (2008: 168-169), the insight is not absent from current debates about resentment and forgiveness: Indeed, it is addressed in the work of R. Jay Wallace (1994), Margaret Walker (2006), Charles Griswold (2007), and others. Thus, his intended audience is unclear.

Apologies are not the central focus of Brudholm's book, but it is interesting, for our purposes, to consider how they might fit into his analysis-or indeed, what his insights about the moral features of resentment reveal about the value of apologies. Ultimately, argues Brudholm following Améry, "a kind of reconciliation between peoples can build on a common refusal of reconciliation with the past" (2008: 116). This resonates nicely with the functions of apology I described above: namely, narrative, disavowal, and commitment. Apologies are not only official records and acknowledgments of past wrongdoings (and government responsibility thereof) but they can also function of authoritative condemnations of the same. As such, they can contribute to a "common refusal of reconciliation" with past wrongs on behalf of those who once perpetrated and endorsed them, or those who now represent or inherit the mantle of the perpetrators. Brudholm has demonstrated how responsibility for reconciliation and for the difficult business of "managing the past" can fall, unfairly and asymmetrically, on the shoulders of victims. In the 2008 apology for Canada's residential schools, PM Harper states:

The burden of this experience has been on your shoulders for far too long. The burden is properly ours as a Government and as a country. There is no place in Canada for the attitudes that inspired the Indian Residential Schools system to ever again prevail. You have been working on recovering from this experience for a long time and in a very real sense, we are now joining you on this journey. (Harper 2008) 
As theorists of apology continue to navigate how we might best identify, understand and critique the sudden plethora of political apologies on the global stage, understanding the power of official narrative, disavowal, and condemnation to shift responsibility to where it belongs is perhaps an excellent place to start.

\section{Notes}

1. See, for example, Nobles (2008) — discussed in detail below—as well as Smith (2008) and Oliner (2008). Janna Thompson refers to an epidemic of apology in a slightly earlier work, whose focus is more broadly on efforts to respond to historical injustices (Thompson 1992).

2. In the former case, the refusal is more extreme than in the latter; the Turkish government refuses to acknowledge that any genocide occurred. Such acknowledgement (i.e., that a genocide against the Armenian people did occur and that the Turkish government is culpable for it) is a necessary condition for apology, since, among other tasks, apologies perform a narrative function: They identify the story of wrongdoing as such. See my discussion of Austin on p. [376] for further discussion. In the US example, no one will deny that slavery occurred, but few are willing to accept a level of responsibility that would entail financial liability or reparations.

3. The texts of the apology and the report are both available online. See Rudd (2008) and "Bringing Them Home" (1997).

4. Or, on the other hand, the decision may also reveal the exceptionalism with which North American academics continue to approach the phenomenon of the War on Terror, in general. The two essays on the topic do not convince me that the War on Terror resists the kind of analysis offered for other forms of internal state or international apologies, or that it is the only phenomenon to transcend the boundaries between the two.

5. Nicholas Tavuchis originally provided a standard typology of apologies: distinguishing between interpersonal or One-to-One apologies, and One-to-Many, Many-to-One, and Many-to-Many (Tavuchis, 1991: 48). Melissa Nobles distinguishes between apologies offered by: (1) heads of state and government officials, (2) governments, (3) religious institutions, (4) organized groups and individual citizens, (5) nongovernmental organizations and institutions, and (6) private institutions (Nobles 2008: 4).

6. This point is taken from personal correspondence with Cels regarding her ongoing research. For more information on her work in progress, see Cels (2010).

7. Admittedly, the mechanics of edited volumes rarely allow for extensive coordination between individual contributors. Thus I take these inconsistencies to be understandable, even expected, given the current state of the literature, and not indicative of particular editorial failings. But the wider lack of engagement between individual theorists is lamentable.

8. As one contributor to The Age of Apology notes, apologies may look like—and mean-very different things in different parts of the world (Alison Dundes Renteln, "Apologies: A CrossCultural Analysis"). Another contributor, Elizabeth Dahl, draws out ways in which practices of giving and receiving apologies are gendered as well as culturally situated apologize (Elizabeth Dahl, "Is Japan Facing Its Past? The Case of Japan and its Neighbors").

9. For example, in Canada, there are still issues arising from the gendered nature of registered Indian status. According to the Indian Act, an Indian woman who married a white man would lose her Indian status, as would her children, even if she remained on the reservation (the same was not true for an Indian man who married a white woman). This was not changed until Bill C-31 in 1985, and its consequences are still being felt by the now-adult children of indigenous women and non-indigenous men, today. In fact, a bill to rectify the differential treatment of indigenous women and indigenous men was introduced by the Canadian government on March 11, 2010. If passed, this bill would effectively render a further 45,000 Canadians eligible for Indian Status. See "New Law to Extend Indian Status to Thousands" (2010).

10. Many official statements of regret, or indeed, reconciliation, will stop short of responsibility and thus apology, in order to avoid incurring financial liability. See Macduff (2009). 
11. Stewart, Jane, Honourable, Minister of Indian and Northern Affairs, "Statement of Reconciliation on behalf of Canada's Government to Canada's Aboriginal Peoples," January 7, 1998.

12. The contrast I emphasize between the 1998 and 2008 statements should not be read as an unqualified endorsement of the latter as a good apology. Indeed, there remain serious points of concern in the wording of the 2008 apology and the policies surrounding it. Nevertheless, as far as determining what qualifies as an official apology (imperfect or otherwise) goes, this example is fairly unambiguous, as indicated in the following sentence: "Therefore, on behalf of the Government of Canada and all Canadians, I stand before you, in this Chamber so central to our life as a country, to apologize to Aboriginal peoples for Canada's role in the Indian Residential Schools system." PM Harper goes on to say, "[T]he Government of Canada sincerely apologizes and asks the forgiveness of the Aboriginal peoples of this country for failing them so profoundly" (Harper 2008). www.fns.bc.ca/pdf/TextofApology.pdf (Accessed March 18, 2009).

13. I have argued elsewhere that our approach to understanding practices of moral repair such as forgiveness and apology should be plural and particularistic, focusing in part on how individual instances are understood and interpreted by those involved (MacLachlan 2009).

14. See Griswold (2007), Norlock (2009), and MacLachlan (2009).

\section{References}

AUSTIN, J. L. (1975) How to do Things with Words (Oxford: Oxford University Press).

BAVELAS, Janet. (2004) An Analysis of Formal Apologies By Canadian Churches to First Nations. Occasional Paper presented to the Centre for Studies in Religion and Society, University of Victoria. [Online]. Available: http://web.uvic.ca/psyc/bavelas/2004ChurchApol.pdf [18 March 2009].

BRINGING THEM HOME: REPORT OF THE NATIONAL INQUIRY INTO THE SEPARATION OF ABORIGINAL AND TORRES STRAIT ISLANDER CHILDREN FROM THEIR FAMILIES. (1997) April. [Online]. Available: http://www.humanrights.gov.au/Social_Justice/ bth_report/report/index.html [12 March 2009].

CARD, Claudia. (2002) The Atrocity Paradigm: A Theory of Evil (New York: Oxford University Press).

CELS, Sanderijn. (2010) Personal Research Website. [Online]. Available: http://cbuilding.org/about/ bio/sanderijn-cels [23 March 2010].

CUNNINGHAM, Michael. (2004) Apologies in Irish politics: A commentary and critique. Contemporary British History, 18(4), 80-92.

FONTAINE, Phil, Chief of the Assembly of First Nations. (2008) Response to Canadian Government Apology, June 11. [Online]. Available: http://www2.canada.com/vancouversun/news/ story.html?id=18133d91-b8aa-4fbe-956e-20298d79c1d5 [18 March 2009].

GIBNEY, Mark, and ROKSTROM, Erik. (2001) The status of state apologies. Human Rights Quarterly, 23, 9-39.

GIBNEY, Mark, HOWARD-HASSMAN, Rhoda E., COICAUD, Jean-Marc, and STEINER, Niklaus. (2008) The Age of Apology: Facing up to the Past (Philadelphia: University of Pennsylvania Press).

GRISWOLD, Charles. (2007) Forgiveness: A Philosophical Exploration (New York: Cambridge University Press).

HARPER, Stephen, Right Honourable, Prime Minister of Canada (2008) Statement of Apology to former students of Indian Residential Schools, June 11. [Online]. Available: www.fns.bc.ca/pdf/ TextofApology.pdf [18 March 2009].

INDIAN RESIDENTIAL SCHOOLS SETTLEMENT AGREEMENT. (2006) [Online]. Available: http://www.residentialschoolsettlement.ca/settlement.html [17 March 2009].

LAZARE, Aaron. (2004) On Apology (Oxford, UK: Oxford University Press). 
MACDUFF, Anne. (2009) Do sorry statements make you liable? The Australian legal context. In Forgiveness: Probing the Boundaries, S. Bloch-Schuman and D. White (ed.) (Oxford: Interdisciplinary Press).

MACLACHLAN, Alice. (2009) Practicing imperfect forgiveness. In Feminist Ethics and Social and Political Philosophy: Theorizing the Non-Ideal, Lisa Tessman (ed.) (New York: Springer Books).

NEW LAW TO EXTEND INDIAN STATUS TO THOUSANDS. (2010) CBC News Online. [Online]. Available: http://www.cbc.ca/canada/north/story/2010/03/11/status-indian.html [22 March 2010].

NOBLES, Melissa. (2008) The Politics of Official Apologies (Cambridge, UK: Cambridge University Press).

NORLOCK, Kathryn. (2009) Forgiveness from a Feminist Perspective (New York: Lexington Books).

OLINER, Samuel P. (2008) Altruism, Intergroup Apology, Forgiveness and Reconciliatin (St. Paul, MN: Paragon House).

RUDD, Kevin, Right Honourable, Prime Minister of Australia. (2008) Apology to Australia's Indigenous Peoples, February 13. [Online]. Available: www.aph.gov.au/house/rudd_speech.pdf [18 March 2009].

SMITH, Nick. (2008) I Was Wrong: The Meaning of Apologies (New York: Cambridge University Press).

STEWART, Jane, Honourable, Minister of Indian and Northern Affairs. (1998) Statement of Reconciliation on behalf of Canada's Government to Canada's Aboriginal Peoples, January 7. [Online]. Available: http://www.deal.org/content/index.php?option=com_content\&task $=$ view\&id $=889 \&$ Itemid $=1082$ [18 March 2009].

TAVUCHIS, Nicolas. (1991) Mea Culpa: A Sociology of Apology and Reconciliation (Stanford: Stanford University Press).

THOMPSON, Janna. (1992) Taking Responsibility for the Past: Reparations and Historical Injustice (Cambridge: Polity Press).

VERDOOLAEGE, Annelies. (2006) Managing reconciliation at the human rights violations hearings of the South African TRC. Human Rights and Negative Emotions: Special Issue of the Journal of Human Rights, 5(1), 27-44.

WALKER, Margaret Urban. (2006) Moral Repair: Reconstructing Moral Relationships after Wrongdoing (New York: Cambridge University Press).

WALLACE, R. Jay. (1994) Responsibility and the Moral Sentiments (Cambridge: Harvard University Press).

WEYENETH, Robert R. (2001) The power of apology and the process of historical reconciliation. The Public Historian, 23(3), 9-30. 